\title{
Negative Political Advertising: It's Impact on Voters
}

\author{
Ernest Cyril de Run \\ Universiti Malaysia Sarawak \\ Jee Teck Weng \\ Swinburne University of Technology Sarawak \\ Lau Wee Ming \\ SEGi College Sarawak
}

\begin{abstract}
This study looks at a one of the many use of a direct negative advertisement in Malaysian politics. Negative advertising has been constantly used by political parties in Malaysia. This paper looks specifically at one of such advertisements and its effect on voters where it was specifically aimed at (Batang Ai, Sarawak). The study measures attitude towards the advertisement, advertisement likeability, advertisement believability, positive emotional quotient towards the advertisement and its affect on actual behavior. Response was obtained from Batang Ai voters and divided into two groups, Barisan Nasional and non-Barisan Nasional voters. A total of 150 respondents were used in this study and the data were analyzed using descriptive analysis, Independent Sample t-test, Correlation and Regression. The findings indicate significant difference between Barisan Nasional and non-Barisan Nasional for all variables except for attitude towards the advertisement. It also shows that advertising believability is the only variable that impacts actual behavior.
\end{abstract}

Keywords: Political Advertising, Advertisement, Malaysia

\section{Introduction}

Social and political advertisements studies have increased over the years (Greening \& Gray, 1994). Much of such studies were mainly developed and carried out in the United States and some parts of Europe (Jasanoff, 2005). However, little attention has been placed on the development of political advertisements studies, especially negative political advertisements in Malaysia. This may be due to the fact that most political advertisements in Malaysia were about a particular candidate or the political party aspirations and promises. There were some indirect negative advertisements too. Hence, the focus here is the use of a direct political advertisement in the previous by-election in Malaysia, particularly the Batang Ai by-election.

The 2008 general election have shown a tremendous transformation in Malaysia's political and governing policies. It has brought about significant changes to the Malaysian political landscape, such as governance innovations and transformations (Ramesh \& Fritzen, 2009). 
Such transformation was especially evident due to the stronger and larger uprising of the middle class as compared to the 1999 election. The middle class had emerged as a force in Malaysian politics since the 1999 election (Loh \& Saravanamuttu, 2003a, 2003b) and were now more evident in the political landscape. The 2008 general election also saw the rise of a coalition opposition party, Pakatan Rakyat (PR). Pakatan Rakyat is a political coalition between three parties, Democratic Action Party (DAP), Parti Keadilan Rakyat (PKR) and Parti Islam Semalaysia (PAS) against the political agenda being pushed by the ruling party (Barisan National). In 2008, the Barisan National (BN) did not lose the election, but the opposition won an impressive five states (Kelantan, Kedah, Penang, Perak and Selangor) (Mohamad, 2008).

The opposition parties and the middle class utilized the Internet (blogs initially and now social media such as Facebook and Twitter), independent newspapers, online news, radio, or alternative media to spread their political agenda and views (George, 2007). What was highlighted was mainly the malpractices and corruption in the nation. On the other hand, the Barisan Nasional (BN), through the federal government, mainly used the main stream media such as those owned by Media Prima (TV3, NTV7, TV9) and main newspaper agencies (Utusan, The Star). The existing media channel such as TV1 and TV2 (owned by national broadcaster, Radio Television Malaysia or RTM in short) and Bernama news agency are clearly seen as the mouthpiece of the government and hence that of Barisan Nasional (George, 2007).

In the recent by-election held at Batang Ai, Sarawak, East Malaysia, two of the political parties (Barisan Nasional and Pakatan Rakyat) was vociferous in their debate. The political competition based on a variety of issues that were employed by both parties was common in Malaysia, until a particular advertisement (refer to Figure 1) appeared in the local newspapers. The advertisement showed a photo of a portion of Permatang Pauh (a town in West Malaysia) which is the Parliamentary seat for the opposition leader Datuk Seri Anwar Ibrahim. The advertisement shows that Permatang Pauh looks undeveloped, and asks the voters in Batang Ai "can the person who manage this place create change for Batang Ai?" This was a deviation from the norm of political advertisements in Sarawak, where a direct negative accusation to a person in the opposition is used, instead of the norm of the party or ideologies. Nevertheless, this is not the first time the BN employed negative advertisement. In the 1999 election, the ruling party aggressively used negative advertisements to discredit the opposition (Kaid \& Holtz-Bacha, 2006; Moten, 2000). The same thing happened in the 1990's election. This strategy had also been used in other elections prior to 1990 (Moten, 2000).

The research will look into the perception of voters in Batang Ai on the above stated political advertisement, dividing respondents into Barisan Nasional and Opposition supporters. The advertisements will be tested for recognition among these respondents (how much do they recognize the message brought up in the advertisement). Other factors looked into are voters attitude towards the advertisement, voters affect (feelings) towards the advertisement, and decision making in order to determine the impact of the advertisement on both Barisan Nasional as well as the Opposition supporters. The rest of the paper is organized as follows: first discussion of the relevant literature is presented; then methodology and findings; followed by discussion of the findings and conclusions including academic and managerial implications, limitations, and areas for future research are discussed. As negative political advertisements have been used widely in the past, it is pertinent to note its effect on voters, be it supporters of the party that placed the advertisement or the other parties. This would allow 
for justification for such use or for it not to be used and further recommendations as to the best way to advertise in order to gain votes.

\section{Literature Review}

\section{Political advertisements}

The use of political advertisement in Malaysia has been extensive over the past years, particularly as elections beckons. Nevertheless, in the past, such intense uses of political advertisement were mainly to serve as a mean of a communication tool for a party. It has been intensively used by various political parties and electoral candidates for the past two decades (Moten, 2009). Previous research done shows that the uses of political advertising assists candidates to be better known through establishing popularity, enable the candidate to connect with a particular demographic groups, attract new supporters, stimulate voters participation in the campaign, raising fund for the candidate and party involved, and ultimately attacking the opponent (Munira, 2012). Nevertheless, such intense uses of political advertisement have created a considerable negative effect of its uses in politics.

The first use of political advertisements date back decades ago. The first country that used such form of political campaign was the United States of America (Valentino, Hutchings, \& Williams, 2004). The advertisements were shown in 1952 in the "Eisenhower Answers America" advertising campaign which addresses more evidence of the relationship between politics and television in the United States. Such use of political advertisement was identified by political and social studies scholars not only as an effective communication tool in promoting a candidates, but also enable to reshape the image of the competing candidate in any election (McGinnis, 1969; Valentino, et al., 2004).

Nevertheless, there are also scholars that have pointed out the ineffectiveness of political advertisements towards cultivating public trust towards such advertisement as a source of useful information (West, 1997). This as such uses of political advertisement have created a substantial "negativity" effects, not predominantly on the candidates, but from the voters perspective. Past studies have found that the uses of negativity in political advertisement will raise cynicism among voters (Ansolabehere \& Iyengar, 1995; Cappella \& Jamieson, 1997), hence discourage voters to participate in politics. This then demobilize them in being involved politics, which is not what politicians want and need (they need voters to vote for them) (Valentino, et al., 2004). Studies done by Goldstein and Freedman (2002) on the other hand found that as the negativity in a political advertisement rises, voters turnout also rises. This indicated that negativity had a strong and positive impact on voter turnout. But this does not necessary mean that it will definite effect voter voting decision when they cast their votes.

Nevertheless, the argument that says whether political advertisements are effective or not still rages on and is mostly concentrated on the US congress and presidency electoral campaign (Holbert, Benoit, Hansen, \& Wen, 2002; Johnson-Cartee \& Copeland, 1989; Valentino, et al., 2004; Watternberg \& Brians, 1999). Most of such studies were focused on the impact of negative political advertising (television news use, and newspapers) on voter's knowledge during the election campaign (Holbert, et al., 2002; Watternberg \& Brians, 1999). Such advertisements were mainly used by political parties to attack their rivals through the issues of which their rivals stand and the party their rivals are affiliated to (Surlin \& Gordon, 1977). 
Hence, the interest of this study is to look at the impact of such political advertisement within a Malaysian context.

\section{Political advertisement in Malaysia}

Political advertisements had been used in Malaysia for some time (since the 60's), but the recent development during 11th general election campaign in Malaysia has witness changes in political campaigns and the use of advertisements in television, newspapers and other media (Kaid \& Holtz-Bacha, 2006). Nevertheless, such changes in Malaysia political arena dated back in 1969 election, where it was the turning point in changing political campaigns in Malaysia (the uses of media such as newspaper to disseminate information to voters) (Ratnam \& Milne, 1970). Nevertheless, the contemporary political campaigns in Malaysia now mainly have evolve from mainly relying on the use video tapes, banners, and flyers to advertise their agenda to using mainstream media (electronic and printed) and the world wide web (Kaid \& Holtz-Bacha, 2006). During the 10th general election, the ruling party (Barisan Nasional) mainly used mass media such as television and newspapers to promote their party and aggressively attack the opposition party and its candidates. This is not surprisingly to know as the BN had been using the mainstream media to as their mean to campaign since its existence in Malaysia (Kuppuswamy, 1999). Such use of mainstream media by BN even for negative campaigning in Malaysia is not exceptional.

Negative campaign in Malaysia has been the mainstay of Malaysian politics for a long time. In 1990, the BN attacked the then opposition coalition leader, Tengku Razaleigh, by posting his picture wearing a Kadazan Dusun headgear with a cross emblem on the newspapers. Such negative campaigning had been used so often in the past, where such aggressive move by the ruling party was strongly criticized by the voters and international onlookers (Lim \& Har, 2008). Hence the Prime Minister of Malaysia at that time, Tun Abdullah Badawi amended the Malaysian political advertising code and ethics (through Malaysia Communication and Multimedia Commission and Malaysia Election Committee) during the 11th general election to a friendlier one. Such a move was mainly meant to promote his image as a tolerant leader rather than attacking the opposition and independent candidate (Kaid \& Holtz-Bacha, 2006).

The use of advertisement bacalum or negative advertisement by the ruling coalition (Lim \& Har, 2008) has created fear of voting and supporting of the opposition parties and candidates among the voters during the last 11th national general. The issues that been raised in such bacalum advertisements, were derived from the idea of creating an Islamic state by the opposition, especially Parti Islam se-Malaysia (PAS). Similar approaches were also implied by the ruling part during the 12th general election and various by-election (Bukit Gantang, Permatang Pauh, Bangan Pinang, etc), where the ruling parties were trying to create fear of inability by the opposition coalition to develop the nation, if the parliamentary and state seat won by the opposition (Lim \& Har, 2008).

\section{Batang Ai By-Election Scenario}

In order to understand the situation in Batang $\mathrm{Ai}$, the reader should be aware of its political history. Batang Ai is a district in Sri Aman division. Sri Aman was previously known as Simanggang but later changed to Sri Aman after the Deklarasi Sri Aman. Simanggang was a military base for the Brooke administration to fight the local Iban rebels from Ulu Batang Ai such as in the Ekspedisi Ulu Ai Pertama (Oktober 1875), Ekspedisi Ulu Ai Kedua (Disember 1875), Ekspendisi Kolera, Delok (9 Jun 1902), Ekspedisi Menyebat dan Engkari (4 Oktober 
1902), Ekspendisi Ulu Ai, Pau (8 November 1902), Ekspedisi Menentang Delok (1 September 1908) and Ekspedisi Ke Delok \& Jengin (2 November 1915). These Iban rebels were quelled after some bloody fighting but the situation in Batang Ai is very closely linked to the Ibans. Batang Ai later became settled and peaceful with the Brookes in 1920 when Perjanjian Damai Dayak was signed on the 4th of August 1920. After World War II, Sarawak became a colony of Britain and on 16 September 1963, Sarawak joined Malaya, creating Malaysia.

Batang Ai is now part of Sri Aman Division which is located within the Lubok Antu parliamentary seat. Lubok Antu District still has a heavy concentration of Ibans, making up about $95 \%$ of the total population (Jali et al., 2012), accounting for 2,338 square kilometer of total land. Batang $\mathrm{Ai}$ at the other hand is 1,341 square kilometer with a population of about 22000, also mainly made up of the Ibans. Most of these Ibans still residing in longhouses by the riverbanks and Batang Ai hydroelectric dam. The people in Batang Ai relies heavily on jungle and river produce as their source of food and income. Some of the people in Batang Ai are still residing deep in the jungle bordering with Kalimantan and having little access to the modernize world. However, most of the Ibans have been relocated to the new resettlement just outside of the Batang $\mathrm{Ai}$ hydroelectric dam after the hydroelectric dam was commissioned on August 21, 1985 (Sim, 2011).

On 7th April 2009, Batang Ai held a by-election when its assemblyman, Datuk Dublin Unting, passed away on 24th February 2009. The state seat in the Lubok Antu parliamentary constituency is known as N.29 Batang Ai. This by-election was held simultaneously with the Bukit Gantang by-election in Perak. In the 2006 state election, Datuk Dublin Unting defeated Nicholas Bawin Anggat from the Sarawak National Party (SNAP) with 804 majority votes. In this predominantly Iban seat, the BN named Malcolm Mussen anak Lamoh as its candidate. The opposition party, Parti Keadilan Rakyat (PKR) which is led by Malaysia's former deputy Prime Minister, Datuk Seri Anwar Ibrahim named former Lubok Antu Member of Parliament, Jawah Gerang, as their candidate.

One of the issue's that was used by both political parties in the Batang Ai by-election was the native land issue. The Ibans are considered natives in Malaysia because they are "son of the soil" of Sarawak. The Ibans and many other natives are unhappy with the Native Customary Land (NCL) or Native Customary Reserve (NCR) laws on ownership of land, where arguments have broken up between state development agencies and private consortiums on issues such as logging, oil palm plantations and hydroelectric dam construction (Sim, 2011). This issue has a strong influence on the natives of Sarawak, where various political parties uses this NCL or NCR issues to gain support from the natives. Nevertheless, this issue is apparently not strong enough to swing the vote of the natives from $\mathrm{BN}$ to $\mathrm{PR}$ as the $\mathrm{BN}$ politics of development still has a strong root among the voters in Sarawak as a whole (Jali, et al., 2012).

Politics of development here encompass the NCL or NCR land issues. What the BN promise to bring in to Sarawak, in this case the people of Batang Ai constituency is the promises of bringing in more development projects into the area, that in return will enhance Batang Ai people socio-economic status (Jali, et al., 2012). Two of the favorite promises by the vast rural people of Sarawak, especially the natives are communication and transportation development (Aeria, 1997). These issues has been successfully addressed by the BN, hence leading to their gaining of more votes from the natives as compare to their counterpart in the urban area of Sarawak. 
Other issues of concern by the people in Batang Ai, and generally Sarawakian, include better road condition, availability of schools, churches and more government kindergardens for the future generation (Jali, et al., 2012). These issues nevertheless do have its own grips on some votes from the natives if it is successfully being grasped by any political party. This is evident in Batang Ai by-election where the candidate of the BN successfully and widely used, alongside the promises of communication and transportation development to win the heart of the vast rural people in Batang Ai, hence transpire into more majority votes in the last Batang Ai by-election in 2009.

\section{Prospect Theory and the Elaboration Likelihood Model (ELM)}

It is noted that Prospect Theory and the Elaboration Likelihood Model (ELM) has been used in order to understand and describe the emotional effects of advertisements (Parker, 2009). One of the difficulties encountered when trying to understand consumer reactions to external market sources of information, is that this information will be viewed with varying degrees of ambiguity or uncertainty. Prospect theory has shown that assumptions of rationality do not accurately reflect consumers' behavior in the face of uncertainty (Kahneman \& Tversky, 1979). This is certainly true with respect to political adverts. The ELM states that consumers make decisions based on cognition or peripheral attributes. Persuasion based on peripheral decision is based on emotive cues without deep processing of information (Petty, Cacioppo, $\&$ Schumann, 1983). This is especially true when the information source is seen as uncertain and ambiguous. As past studies have indicated that when there is a negative political advertisement, cynicism will increase and it will affect voters' participation and support towards the party that employed negative advertising (Ansolabehere \& Iyengar, 1995; Cappella \& Jamieson, 1997; Valentino, et al., 2004). Hence the purpose of this study to look at the emotional quotient arising from the use of negative political advertising and its impact on the attitude and behavior of voters, from both sides (Barisan Nasional and Pakatan Rakyat). Thus the following hypothesis:

$\mathrm{H}_{1}$ : There will be difference between Barisan Nasional and non Barisan Nasional stalwarts Attitude (favorable or unfavorable evaluation) towards the Advertisement, Like the Advertisement, Advertisement Believability, Emotional Quotient and Voting Behaviour.

$\mathrm{H}_{2}$ : There will be difference in relationship and impact of factors such as Attitude (favorable or unfavorable evaluation) towards the Advertisement, Like the Advertisement, Advertisement Believability, Emotional Quotient and Voting Behaviour for Barisan Nasional and non Barisan Nasional stalwarts. 


\section{Methodology}

Respondents were selected using purposive sampling technique. A pre-established criterion for individual participant selection was determined before visiting Batang Ai. These criteria are: 1 . Respondent must be of voting age and 2 . Respondent must be a registered voter in the constituency. The researchers visited Batang Ai at two separate instances, for a period of four days each. Enumerators were hired to collect data at the various longhouses. Respondents were selected with the help and consent of relevant Tuai Rumah (Village Headman). Respondents were also selected from the town of Batang Ai itself.

A total of 196 respondents were obtained in this study. The sample size calculation was based on a single stage pseudo-experimental design. The authors uses a 2 (type of voter [BN and PR]) x 1 (advertisement) was utilized. Considering a requirement of at least 50 respondents per cell, the minimum number of respondents was calculated at 100 respondents. Sekaran (2003) suggest that a sample size of between 30 to 500 samples would be sufficient for most studies.

\section{Data Collection Instrument}

The data collection instrument was divided into four sections: Section one comprises of items relating to individual demographics. Section two was the depiction of the advertisement (as in Figure 1). The use of only 1 advertisement (Figure 1) in this study is mainly based on the wide availability of the advertisement in the local newspaper during the Batang Ai byelection campaigning period. At the other hand, the message in the advertisement is clearly addressing the development issue in Permatang Pauh and questioning the ability of the opposition party to bring changes to Batang Ai. This hence raised the decision to use only the advertisement from Figure 1 as the point of research in this study.

Section three includes items relating to involvement, emotional quotient, voting choice, voting choice when knowing the advertisement was offensive, attitude towards the advertisement, advertisement likeability, and advertisement believability (Beltramini, 1988). Respondents were asked to respond to a Likert type scale (level of agreement on a scale of 1 to 6 with 6 being strongly agree). This is in order to force answer that is not median based (Chang, 1994). Section four gauged the respondents' views on the advertisement. 


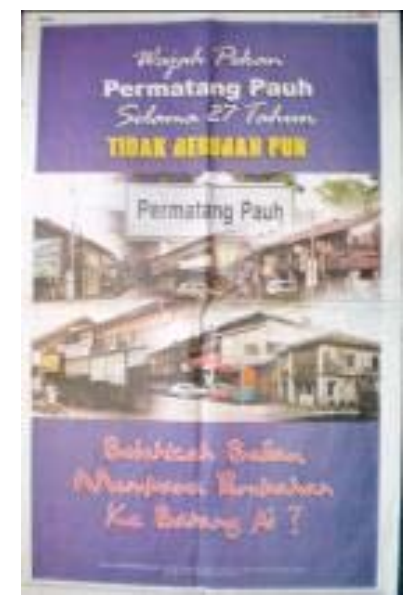

\section{Figure 1: Advertisement Used in the Study}

Data from the voting choice was used to categorize respondents into two groups. Those that scored high (5 to 6) to the question "If I had voted, I would have voted for the political party that made this advertisement (Barisan Nasional)," were coded as Barisan Nasional voters. Those that scored between 1 to 2 to the same question were coded as non-Barisan Nasional voters as they clearly disagree with the question. Similar methods have been used in previous research in advertising (De Run, 2005). This study only looked at the views of Barisan Nasional and non-Barisan Nasional voters. A total of 70 respondents from Barisan National voters and 80 respondents from non-Barisan Nasional voters were used. The data was then analyzed using Means and difference test (Independent Sample t-test) to test the difference for the observed variables in this study. A correlation and simple regression was also carried out. 


\section{Findings}

Respondents profile is depicted in Table 1.

Table 1: Respondents Profile

\begin{tabular}{|c|c|c|c|c|c|}
\hline \multirow{2}{*}{ Variable } & & \multicolumn{2}{|c|}{$* \mathbf{B N}$} & \multicolumn{2}{|c|}{$* *$ Non-BN } \\
\hline & & Freq & $\%$ & Freq & $\%$ \\
\hline \multirow[t]{2}{*}{ Gender } & Male & 33 & 47.1 & 40 & 50.0 \\
\hline & Female & 35 & 50.0 & 40 & 50.0 \\
\hline \multirow[t]{5}{*}{ Age Scale } & $20 \mathrm{~s}$ & 24 & 34.3 & 25 & 31.3 \\
\hline & $30 \mathrm{~s}$ & 16 & 22.9 & 21 & 26.3 \\
\hline & $40 \mathrm{~s}$ & 11 & 15.7 & 13 & 16.3 \\
\hline & $50 \mathrm{~s}$ & 8 & 11.4 & 10 & 12.5 \\
\hline & 60 and older & 11 & 15.7 & 11 & 13.8 \\
\hline \multirow[t]{5}{*}{ Education } & No formal education & 22 & 31.4 & 13 & 16.3 \\
\hline & Primary & 5 & 7.1 & 15 & 18.8 \\
\hline & Secondary & 39 & 55.7 & 44 & 55.0 \\
\hline & Diploma & 3 & 4.3 & 7 & 8.8 \\
\hline & Graduate & 1 & 1.4 & - & - \\
\hline \multirow[t]{3}{*}{ Ethnicity } & Iban & 67 & 95.7 & 77 & 96.3 \\
\hline & Malay & 1 & 1.4 & 1 & 1.3 \\
\hline & Chinese & 2 & 2.9 & 1 & 1.3 \\
\hline
\end{tabular}

$* \mathrm{BN}=$ Barisan Nasional, $* *$ Non-BN $=$ Non-Barisan Nasional

The means and t-test for the variables observed by each voter's preference (Barisan Nasional or Non-Barisan Nasional) are depicted in Table 2. It is clear that there are differences in liking the advertisement, advertisement believability, emotional quotient (see Table 2), and voting preferences.

Table 2: Means and t-test of Responses by Voting Preference

\begin{tabular}{lcccc}
\hline \multirow{2}{*}{ Variable } & \multicolumn{2}{c}{${ }^{*} \mathbf{B N}$} & \multicolumn{2}{c}{$* *$ Non-BN } \\
\cline { 2 - 5 } & Mean & S.D $^{\#}$ & Mean & S.D $^{\#}$ \\
\hline $\begin{array}{l}\text { Attitude towards the Advertisement } \\
(\mathrm{t}=-0.524, \text { Sig=.601) }\end{array}$ & 4.17 & 1.05 & 4.07 & 1.20 \\
\hline $\begin{array}{l}\text { Like the Advertisement } \\
(\mathrm{t}=-2.982, \text { Sig=.003) }\end{array}$ & 4.53 & 1.88 & 3.56 & 2.10 \\
\hline $\begin{array}{l}\text { Advertisement Believability } \\
(\mathrm{t}=-3.097, \text { Sig=.002) }\end{array}$ & 4.31 & 1.08 & 3.78 & 0.99 \\
\hline $\begin{array}{l}\text { Positive Emotional Quotient } \\
(\mathrm{t}=-2.806, \text { Sig=.006) }\end{array}$ & 4.04 & 0.65 & 3.66 & 0.95 \\
\hline $\begin{array}{l}\text { Vote BN } \\
(\mathrm{t}=-57.22, \text { Sig=.000) }\end{array}$ & 5.69 & 0.47 & 1.31 & 0.47 \\
\hline
\end{tabular}

*BN $=$ Barisan Nasional, **Non-BN = Non-Barisan Nasional \# Standard Deviation 
Table 3 depicts the correlation for the variables observed by each voter's preference (Barisan Nasional or Non-Barisan Nasional). It is clear that there is a correlation between vote BN and advertisement believability for both voting preference.

Table 3: Pearson Correlation Test by Voting Preference

\begin{tabular}{|c|c|c|c|c|c|c|c|c|}
\hline Variables & \multicolumn{4}{|c|}{${ }^{*} \mathbf{B N}$} & \multicolumn{4}{|c|}{$* *$ Non-BN } \\
\hline & 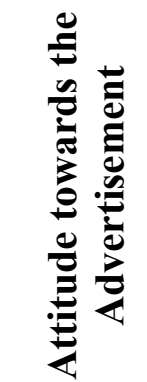 & 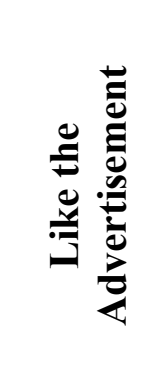 & 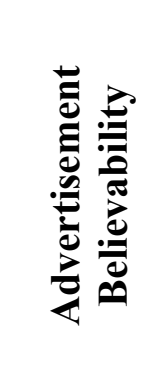 & 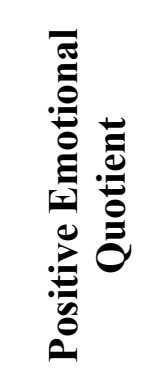 & 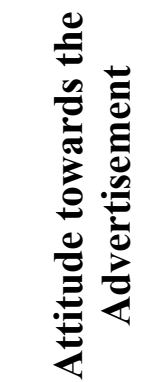 & 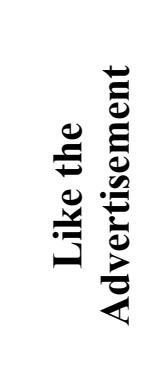 & 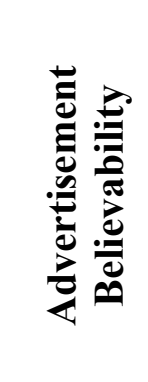 & 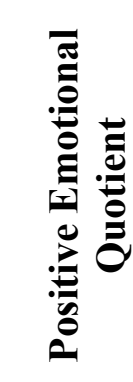 \\
\hline $\begin{array}{l}\text { Vote } \\
\text { BN }\end{array}$ & $\begin{array}{l}0.047 \\
(0.708)\end{array}$ & $\begin{array}{l}-0.039 \\
(0.748)\end{array}$ & $\begin{array}{l}0.216 \\
(0.080)\end{array}$ & $\begin{array}{l}0.142 \\
(0.245)\end{array}$ & $\begin{array}{l}-0.158 \\
(0.175)\end{array}$ & $\begin{array}{l}-0.130 \\
(0.255)\end{array}$ & $\begin{array}{l}-0.191 \\
(0.093)\end{array}$ & $\begin{array}{l}-0.092 \\
(0.436)\end{array}$ \\
\hline
\end{tabular}

Standard Regression was then performed in order to understand the effect of voting preference on respondents' attitude towards the advertisement, liking the advertisement, advertisement believability, emotional quotient. The findings show that there is a significant relationship between advertisement believability and vote $\mathrm{BN}$ for $\mathrm{BN}$ voters. Refer to Table 4.

Table 4: Multiple Regression Analysis between Voting Preferences and Respondents' Attitude towards the Advertisement, Liking the Advertisement, Advertisement Believability, Emotional Quotient.

\begin{tabular}{lcc}
\hline Independent Variable & $\begin{array}{c}\text { Standardize Beta } \\
* \text { BN }\end{array}$ & $\begin{array}{c}\text { Standard Beta } \\
* * \text { Non-BN }\end{array}$ \\
\hline Attitude towards the Advertisement & $0.121(0.403)$ & $-0.164(0.254)$ \\
Like the Advertisement & $-0.109(0.427)$ & $-0.104(0.465)$ \\
Advertisement Believability & $0.347(0.010)$ & $-0.114(0.387)$ \\
Positive Emotional Quotient & $0.083(0.535)$ & $0.062(0.668)$ \\
\hline Constant & 4.676 & 1.733 \\
$\mathrm{R}$ & 0.369 & 0.258 \\
$\mathrm{R}^{2}$ & 0.136 & 0.066 \\
Adjusted $\mathrm{R}^{2}$ & 0.076 & 0.008 \\
F Value & $2.282(0.071)$ & $1.138(0.347)$ \\
\hline
\end{tabular}

$* \mathrm{BN}=$ Barisan Nasional, ${ }^{*} *$ Non- $\mathrm{BN}=$ Non-Barisan Nasional 


\section{Discussion}

The findings show that voters who are $\mathrm{BN}$ voters as having a high score on all the variables being measured. This shows a strong level of support towards Barisan Nasional candidate by the Barisan Nasional supporters (Jali, et al., 2012). One must remember that the advertisement is rather negative of the opposition, and directly at that, nevertheless the response to such a negative advertisement was positive by those who preferred to vote for BN. On the other hand, non-Barisan Nasional supporters seem to have a middle of the line response to all variables measured. The only similarity of non-Barisan Nasional voters with Barisan Nasional voters are their overall attitude towards the advertisement, which leans to a more positive level. This finding is in support of past studies that evaluation of the message depends on their motivation to process the advertisement and the message (Maheswaran \& Sternthal, 1990), in this case how the voters see the party, the candidate and the opposition. Hence, Barisan Nasional voters will see such messages as good while non-Barisan Nasional voters will have the opposite reaction.

The findings from this study show that the Barisan Nasional voters like the advertisement (the way the message was packaged). See Table 2. There is a strong and significant difference between $\mathrm{BN}$ and non-BN voters, where BN voters liked the advertisement more. This indicates a positive emotional response to such an advertisement that is more than that of the non-BN voters. It is obvious that non-BN voters would not like such an advertisement.

The likability of the ad can be seen in the measurement of positive emotional quotient, where $\mathrm{BN}$ voters are significantly different from non-BN voters. They have a positive emotional quotient towards the advertisement as shown in this study. Definitely it might not have an effect on their voting choice if they have a low emotional quotient (see Table 2). The findings are also in line with the Elaboration Likelihood Model that explains ambiguity and uncertainty in advertisements used to understand and describe the emotional effects of advertisements (Parker, 2009). When respondents are uncertain of an advertisement, they utilize emotional cues that occur without deep processing of the information being presented in the advertisement (Petty, et al., 1983). They do not really believe and are uncertain of the message in the advertisement. This mainly happen as most of the voters in Batang Ai have never gone to or do not even knows about Permatang Pauh. At the same time, there is no actual rebuttal ability by the Pakatan Rakyat voters against the ruling government, so there is no actual credence towards the advertisement.

The advertisement in the end did not achieve any changes in behavior from the non-Barisan Nasional voters and there was no indication that it strengthened the Barisan Nasional voters' choice either (See Table 2). This as the findings indicated that the non-Barisan Nasional voters are having a marginal attitude, likeability and believability of the advertisement, and positive emotional quotient. Thus this advertisement did not do much to pull more votes towards the Barisan Nasional candidate, except alienate the other voters more (especially the strong PR supporters). This is especially true when looking at influencing the strong partisan voters (voters who have strong attachment to a political party) to be influenced by the election campaigns. These types of voters would vote for the party of their choice regardless of the kind of campaigns and message that the other parties run and disseminate. Issues such as accessibility by various voters towards such advertisement are also of a concern. Batang Ai DUN constituency is a vast rural area where less information on the current political phenomenon in Malaysia are reaching them. Hence, the advertisers should also look into other communication mediums such as the radio and television to connect with the voters. 
Other than that, the issue of illiterate in reading might also dampen the dissemination of information by the advertisers to the voters.

Further analysis indicated that only advertisement believability had a positive correlation with actual behavior (Vote for BN) (see table 3). It was obvious that there was a positive relationship between advertisement believability and voting for $\mathrm{BN}$ for $\mathrm{BN}$ voters and a negative relationship for non-BN Voters. Further analysis using regression confirmed this (see Table 4). This suggest that for voters, advertisement believability is crucial in transforming voters into action, but this is still limited to predisposed beliefs and amount of information available.

Political parties must also be very clear as to why they use various political advertisements (including negative political advertising) as past studies carried out found out that the uses of negative political advertisement will only raises more cynicism among the voters (Ansolabehere \& Iyengar, 1995; Cappella \& Jamieson, 1997), and further discourages voters to participate in politics (Valentino, et al., 2004). Rather than using negative political advertisement in political parties campaigns, the advertisement can be created in a way that it help to disseminate information that is vital to the people such as communication and transportation developments that is relevant to the voters of Sarawak.

\section{Conclusion}

Respondents of this study were Barisan Nasional and non-Barisan Nasional party voters. The findings justify that that this ad bacalum or negative advertisement created a significant different emotional response yet did not change voting decision for the non-Barisan voters. The non-Barisan Nasional voters responses were still quite marginal on their attitude, likeability, believability, emotional quotient and behavior while Barisan Nasional voters were very strong in their response. Only the belief in the facts of the advertisement had an impact on actual behavior.

\section{Limitation and future study}

The respondents in this study were mainly from the native Iban communities residing in Batang Ai under the state seat in the Lubok Antu parliamentary constituency (N29). Most of the voters in this area were from the native Iban communities. Future study can integrate other races such as Malay and Chinese into their study to resemble a better representation of the demographic factors in this area. Future studies could use a larger sample and measure the relationship between these variables. Future studies could also compare positive and negative advertisements to see if there is any difference.

It is noted that the time when the data collection done was on the day of the by-election and after the by-election. There is a possibility that these two different time frames may limit the reliability of the responses gathered. Future study could start the data collection process couple of weeks before any future by-election or totally after the fact. Other studies can look at the situation from before, during and after an election. This will minimize the risk of influence by the competing candidates and parties, thus providing a more accurate and reliable responses from the potential voters towards the advertisement effect alone. 
Other than that, the method to categorize the Barisan Nasional and non-Barisan Nasional voters is weak. Hence future study should clearly identify the voters (either to be Barisan Nasional voters, non-Barisan Nasional voters, Pakatan Rakyat voter, or even independent party candidate voters) clearly. Previous study assesses party attachment prior to the election. In the pre-election period, the respondents should be asked which party they intend to vote. This will allow the author to identify the party attachment of his/her respondents. Then only the author can ask the respondents whether they had come across the Figure 1 advertisement and to capture the respondents' perceptions towards the advertisement.

\section{Recommendation}

Sarawak Iban voters indicate that there are many other underlying issues such as native land, resettlement, employment, security, education, school, basic amenities and transportation that should be the main concentration in a political communication effort (Jali, et al., 2012). The use of negative advertisement is clearly not justified, especially if it's a one off advertisement. Nevertheless, it is notable that there are also various other type of electoral campaign such as the radio and television, other than newspaper advertisement that various political parties can use to disseminate their propaganda and information to the rural folks. Hence, those political parties (Barisan Nasional, Pakatan Rakyat or Independent) should be considering those other mediums disseminating their rhetoric and information to the vast rural area people of Sarawak. What is more important is the believability of the advertisement in inducing action rather than the negativity portrayed.

\section{Acknowledgement}

This research was supported by the Universiti Malaysia Sarawak Small Grant Scheme to Ernest Cyril de Run. Jee Teck Weng is a lecturer at Faculty of Business and Design, Swinburne University of Technology Sarawak Campus. Lau Wee Ming is a Lecturer at Segi College Sarawak as well as a Masters student at the Faculty of Economics and Business, UNIMAS and is supported by Zamalah Unimas.

\section{Reference}

Aeria, A. (1997). The politics of development and the 1996 Sarawak state election. Jurnal Kajian Malaysia, 15(1\&2), 57-83.

Ansolabehere, S. D., \& Iyengar, S. (1995). Going Negative. New York: Free Press.

Beltramini, R. F. (1988). Perceived believability of warning label information presented in cigarette advertising. Journal of Advertising, 17(2), 26-32.

Cappella, J., \& Jamieson, K. H. (1997). Spiral of Cynicism. New York: Oxford University Press.

Chang, L. (1994). A Psychometric Evaluation of 4-Point and 6-Point Likert-Type Scales in Relation to Reliability and Validity Applied Psychology Measurement, 18(3), 205215.

De Run, E. C. (2005). Does targeting really work? The perspective of a dominant ethnic group. International Journal of Business and Society, 6(1), 27-51. 
George, C. (2007). Media in Malaysia: Zone of Contention. Democrazation, 14(5), 893-910.

Goldstein, K., \& Freedman, P. (2002). Lesson learned: Campaign advertising in the 2000 elections. Political Communication, 19(1), 5-28.

Greening, D. W., \& Gray, B. (1994). Testing a model of organizational response to social and political issues. Academy of Management Journal, 37(3), 467-498.

Holbert, R. L., Benoit, W., Hansen, G., \& Wen, W.-C. (2002). The role of communication in the formation of an issue-based citizenry. Communication Monographs, 69(4), 296310 .

Jali, M. F. M., Besar, J. A., Sidek, A. H., Ibrahim, Y., Awal, N. A. M., \& Ismail, K. (2012). Politik pembangunan dalam pilihan raya kecil Dewan Undangan Negeri (DUN) Batang Air, Sarawak. Geografia: Malaysian Journal of Society and Space, 8(2), 8897.

Jasanoff, S. (2005). Designs on nature: science and democracy in Europe and the United States. . USA: Princeton University Press.

Johnson-Cartee, K. S., \& Copeland, G. A. (1989). Southern voters' reaction to negative political ads in the 1986 election. Journalism Quarterly, 89(66), 888-893.

Kahneman, D., \& Tversky, A. (1979). Prospect Theory: An Analysis of Decision under Risk. The Econometric Society, 47, 263 - 291.

Kaid, L. L., \& Holtz-Bacha, C. (2006). The SAGE handbook of political advertising

Kuppuswamy, C. S. (1999). 10th General Election in Malaysia - an Analysis: It is now Malays vs Malays. India: South Asia Analysis Group.

Lim, K. H., \& Har, W. M. (2008). Ad baculum, Islamic state and Malaysian Chinese politics: A rhetorical study of selected Political advertisements in the local Chinese media during the 11th Malaysian general election campaign. Journal of Politics and Law, $1(1), 25-39$.

Loh, F. K. W., \& Saravanamuttu, J. (2003a). New Politics in Malaysia. Singapore: Institute of Southeast Asian Studies.

Loh, F. K. W., \& Saravanamuttu, J. (2003b). Political Culture in Malaysia: Contesting Developmentation in a Multi-Ethnic Society. University of Tokyo, Discussion Papers, No. 9: Institute of Oriental Culture.

Maheswaran, D., \& Sternthal, B. (1990). The effects of knowledge, motivation, and type of message on ad processing and product judgements. Journal of Consumer Research, 17(June), $66-73$.

McGinnis, J. (1969). The Selling of the President. New York: Simon \& Shuster. 
Mohamad, M. (2008). Malaysia - democracy and the end of ethnic politics? Asustralian Journal of International Affairs, 62(4), 441-459.

Moten, A. R. (2000). The 1999 general election in Malaysia: Towards a stable democracy? Akademika: Journal of the Social Science and Humanities, 57, 67-86.

Moten, A. R. (2009). 2004 and 2008 General Elections in Malaysia: Towards a Multicultural, bi-party Political System? Asian Journal of Political Science, 17(2), 173-194.

Munira, S. (2012). Political Advertising. Retrieved from http://www.slideshare.net/munirasulaiman/political-advertising-10835175

Parker, A. C. (2009). Issue advertising: Effects of frame valence and advertising involvement on attitudes and behavior. Florida, USA: University of Florida.

Petty, R. E., Cacioppo, J. T., \& Schumann, D. (1983). Cantral and peripheral routes to advertisinf effectiveness: the moderating role of involvement. Journal of Consumer Research, 10, 135-146.

Ramesh, M., \& Fritzen, S. C. (2009). Transforming Asian Governance: Rethinking Assumptions, Challenging Practices. London: Routledge.

Ratnam, K. J., \& Milne, R. S. (1970). The 1969 Parliamentary Election in West Malaysia. Pacific Affairs, 43(2), 203-226.

Sekaran, U. (2003). Research methods for business. New York: USA: Hermitage Publishing Service.

Sim, H. C. (2011). Coping with change: rural transformation and women in contemporary Sarawak, Malaysia. Critical Asian Studies, 43(4), 595-616.

Surlin, S. H., \& Gordon, T. F. (1977). How values affect attitudes toward direct reference political advertising. Journalism Quarterly, 54, 89-98.

Valentino, N. A., Hutchings, V. L., \& Williams, D. (2004). The impact of political advertisement on knowledge, internet information seeking, and candidate preference. Journal of Communication(June), 337-354.

Watternberg, M. P., \& Brians, C. L. (1999). Negative Campaign Advertising: Demobilizer and Mobilizer? The American Political Science Review, 93(4), 881-899.

West, D. M. (1997). Air Wars: television Advertising in Election Campaigns, 1952-1996 (2nd ed.). Washington DC: Congressional Quarterly 